\title{
E series prostaglandins alter the proliferative, apoptotic and migratory properties of T98G human glioma cells in vitro
}

Renata N Gomes and Alison Colquhoun*

\begin{abstract}
Background: In many types of cancer, prostaglandin $E_{2}\left(P_{G E}\right)$ is associated with tumour related processes including proliferation, migration, angiogenesis and apoptosis. However in gliomas the role of this prostanoid is poorly understood. Here, we report on the proliferative, migratory, and apoptotic effects of $\mathrm{PGE}_{1}, \mathrm{PGE}_{2}$ and Ibuprofen (IBP) observed in the T98G human glioma cell line in vitro.
\end{abstract}

Methods: T98G human glioma cells were treated with IBP, $\mathrm{PGE}_{1}$ or $\mathrm{PGE}_{2}$ at varying concentrations for 24-72 hours Cell proliferation, mitotic index and apoptotic index were determined for each treatment. Caspase-9 and caspase-3 activity was measured using fluorescent probes in live cells (FITC-LEHD-FMK and FITC-DEVD-FMK respectively). The migratory capacity of the cells was quantified using a scratch migration assay and a transwell migration assay.

Results: A significant decrease was seen in cell number (54\%) in the presence of $50 \mu \mathrm{M}$ IBP. Mitotic index and bromodeoxyuridine (BrdU) incorporation were also decreased 57\% and 65\%, respectively, by IBP. The apoptotic index was increased (167\%) and the in situ activity of caspase-9 and caspase-3 was evident in IBP treated cells. The inhibition of COX activity by IBP also caused a significant inhibition of cell migration in the monolayer scratch assay (74\%) and the transwell migration assay (36\%).

In contrast, the presence of exogenous $\mathrm{PGE}_{1}$ or $\mathrm{PGE}_{2}$ caused significant increases in cell number $\left(37 \% \mathrm{PGE}_{1}\right.$ and $45 \% \mathrm{PGE}_{2}$ ). When mitotic index was measured no change was found for either PG treatment. However, the BrdU incorporation rate was significantly increased by $\mathrm{PGE}_{1}(62 \%)$ and to a greater extent by $\mathrm{PGE}_{2}$ (100\%). The apoptotic index was unchanged by exogenous PGs. The addition of exogenous PGs caused an increase in cell migration in the monolayer scratch assay $\left(43 \% \mathrm{PGE}_{1}\right.$ and $\left.44 \% \mathrm{PGE}_{2}\right)$ and the transwell migration assay $\left(28 \% \mathrm{PGE}_{1}\right.$ and $68 \%$ $\left.P G E_{2}\right)$.

Conclusions: The present study demonstrated that treatments which alter $\mathrm{PGE}_{1}$ and $\mathrm{PGE}_{2}$ metabolism influence the proliferative and apoptotic indices of T98G glioma cells. The migratory capacity of the cells was also significantly affected by the change in prostaglandin metabolism. Modifying PG metabolism remains an interesting target for future studies in gliomas.

Keywords: Glioma, Prostaglandin, Ibuprofen, Apoptosis, Migration

\footnotetext{
*Correspondence: alison@usp.br

Department of Cell and Developmental Biology, University of São Paulo, São
}

Paulo CEP 05508-900, SP, Brazil 


\section{Background}

Malignant gliomas and especially Glioblastoma multiforme (GBM) are the most malignant and prevalent intracranial tumours, classified as grade IV by the World Health Organization (WHO). GBMs are characterized by genetic alterations affecting genes that control cell growth, migration, apoptosis, and invasion. Despite very aggressive treatment including surgery and combined radio and chemotherapy the median survival for most patients with GBM is only 1 year. Therefore there is an urgent need for the development of novel therapeutic agents [1,2].

Non-steroidal anti-inflammatory drugs (NSAIDs) are widely used in the treatment of pain, fever and inflammation caused by various physiological or pathological conditions. Clinical trials have demonstrated that longterm NSAID use significantly reduces the risk of colorectal cancer and other tumours such as breast, lung, prostate and gastric cancer [3-5].

NSAIDs are known to inhibit a variety of cellular processes including signal transduction, transcription, and DNA repair. NSAIDs can alter cell cycle distribution, inhibit cyclins, modulate Bcl-2 family proteins and induce apoptosis [6,7]. NSAIDs also inhibit angiogenesis, an important factor necessary for tumour growth and survival, suggesting a rationale for their potential therapeutic application as anticancer agents [8].

The mechanism by which NSAIDs exert their antiinflammatory activity is primarily by inhibiting the synthesis of prostaglandins through inhibition of both cyclooxygenase isoforms (COX-1 and COX-2), the ratelimiting enzyme of the cascade. COX-1 is constitutively expressed in many tissues and plays an important role in the control of homeostasis. Conversely, COX-2 is an inducible enzyme and is activated in response to extracellular stimuli such as growth factors and pro-inflammatory cytokines $[9,10]$.

Several studies have shown COX and PGs play a role in cell growth, survival, migration/invasion and angiogenesis of tumour cells. Accumulating evidence suggests that the increase in overexpression of COX-2 and $\mathrm{PGE}_{2}$ in human glioma is associated with poor prognosis and tumour progression $[11,12]$.

Ibuprofen (IBP) belongs to the group of NSAIDs, and is a potent COX-1 and COX-2 inhibitor. Besides its widespread use in the treatment of inflammatory diseases, it has been shown that IBP may be effective in the treatment and/or prevention of cancers including prostate and colorectal cancer [13-15].

However, the effect of IBP treatment in GBM has not been widely investigated. Recent studies from our laboratory have shown novel ruthenium-containing IBP complexes have significant effects on glioma cell proliferation and apoptosis $[16,17]$. In this study, we aimed to assess the potential effects of IBP on tumour cell proliferation, migration and apoptosis in T98G human glioma cells. The effect of the addition of exogenous $\mathrm{PGE}_{1}$ and $\mathrm{PGE}_{2}$ to the cells was also studied. $\mathrm{PGE}_{1}$ was compared with $\mathrm{PGE}_{2}$ as it has been reported to interact not only with the EP receptors EP3 and EP4 but also with the IP receptor, while $\mathrm{PGE}_{2}$ can interact with all four EP receptors. The cellular response to $\mathrm{PGE}_{1}$ and $\mathrm{PGE}_{2}$ depends on both the expression of receptors and the synthetic capacity of the individual tissue [18].

The study aimed to test the importance of $\mathrm{PGE}_{1}$ and $\mathrm{PGE}_{2}$ metabolism to the proliferative and apoptotic indices of T98G glioma cells. Since prostanoids are also involved in cell migration the effect of IBP, $\mathrm{PGE}_{1}$ and $\mathrm{PGE}_{2}$ on the migratory capacity of the cells was investigated using two migration assays.

\section{Methods}

\section{Cell culture}

T98G cells, derived from a human glioblastoma, were obtained from the ATCC and donated by Prof. S.S. Maria-Engler. Cells were grown in Dulbecco's modified Eagle's medium (DMEM) supplemented with 10\% fetal calf serum (FCS), 50U/ml penicillin, and $50 \mu \mathrm{g} / \mathrm{ml}$ streptomycin. Cells in the exponential phase of growth were used, growing in $75 \mathrm{~cm}^{2}$ flasks in a humidified atmosphere of $5 \% \mathrm{CO}_{2}, 95 \%$ air at $37^{\circ} \mathrm{C}$. After growth to the desired density cells were washed with PBS and trypsinized (trypsin 0.025\%/ EDTA 0.02\%) for subsequent plating. All experiments used cells grown in DMEM with FCS and antibiotics as stated above.

\section{Drug treatment}

Ibuprofen (Cayman Chemicals) was dissolved in ethanol to achieve the stock concentrations desired. $\mathrm{PGE}_{1}$ and $\mathrm{PGE}_{2}$ (Cayman Chemicals) were dissolved in dimethyl sulfoxide (DMSO; Sigma-Aldrich). All drugs were further diluted in DMEM (Gibco BRL) to their final concentration.

\section{Cell proliferation assay}

The cells were treated with IBP $(25-200 \mu \mathrm{M}), \mathrm{PGE}_{1}$ $(0.01-10 \mu \mathrm{M})$ or $\mathrm{PGE}_{2}(0.01-10 \mu \mathrm{M})$ for up to 72 hours in $75 \mathrm{~cm}^{2}$ flasks. After that, the cells were harvested with trypsin (trypsin 0.025\%/ EDTA 0.02\%) and the cell number was determined in an improved Neubauer counting chamber [19]. The cell proliferation assay was conducted three times for each concentration.

\section{Analysis of nuclear morphology}

The IBP, $\mathrm{PGE}_{1}$ or $\mathrm{PGE}_{2}$ treated and control cells were fixed in situ with $4 \%$ formaldehyde in $0.1 \mathrm{M}$ potassium phosphate buffer at $\mathrm{pH} 7.2$. The cells were washed (x3) with PBS, $\mathrm{pH} 7.2$, and incubated with $5 \mu \mathrm{g} / \mathrm{ml}$ Hoechst 
33342 for $5 \mathrm{~min}$ at room temperature. The cells were examined and immediately photographed using a fluorescence microscope (Nikon Optiphot-II epifluorescence microscope equipped with, a Cool Snap Pro camera, and Image Pro plus software). Apoptotic cells can be distinguished from viable cells by their nuclear morphology with nuclear condensation and fragmentation, as well as by the higher intensity of blue fluorescence of the nuclei. The mitotic index was determined by the number of cells in cell division. A total of 200 cells were counted in multiple randomly selected fields, and the percentage of apoptotic and mitotic index cells were then calculated per total cell number.

\section{Migration assay}

Cells were plated into $30 \mathrm{~mm}$ petri dishes $\left(1.5 \times 10^{5} /\right.$ dish) and maintained in a humidified atmosphere of $5 \%$ $\mathrm{CO}_{2}: 95 \%$ air at $37^{\circ} \mathrm{C}$. During the given period of 48 hours, the cells were treated daily with IBP $(25 \mu \mathrm{M}$ and $50 \mu \mathrm{M}), \mathrm{PGE}_{1}(10 \mu \mathrm{M})$ or $\mathrm{PGE}_{2}(10 \mu \mathrm{M})$. Before the end of treatment, the cell layer was scraped with a sterile razor blade (marking the point of zero migration) and the petri dish returned to the incubator for a further 10 hours in the presence of treatments. At the end of this 10 hours incubation period, the cells were fixed in situ with $4 \%$ formaldehyde in $0.1 \mathrm{M}$ potassium phosphate buffer at pH 7.2. The cells were washed (x3) with PBS, pH 7.2, and incubated with $5 \mu \mathrm{g} / \mathrm{ml}$ Hoechst 33342 for $5 \mathrm{~min}$ at room temperature. The samples were washed (x3) with PBS, pH 7.2, before mounting in SlowFade mounting medium. Cells were analyzed with a Nikon Optiphot-II epifluorescence microscope equipped with, a Cool Snap Pro camera, and Image Pro plus software. The results were expressed as the number of migrating cells per $\mathrm{mm}^{2}$ of scratched area of petri dish [20].

\section{Transwell migration assay}

A second migration assay was performed using the 24well Boyden chamber plate with 8 - $\mu \mathrm{m}$ pore size polycarbonate membrane filters. T98G cells $\left(5 \times 10^{4} /\right.$ well $)$ were placed in the upper part of the Boyden chamber containing DMEM and 10\% FCS, the lower chamber also contained DMEM and 10\%FCS. After a period of cell adhesion $(12 \mathrm{~h})$ the medium was changed and treatment (IBP, $\mathrm{PGE}_{1}$ and $\mathrm{PGE}_{2}$ ) was added to both parts of the chamber. The culture media with treatment was changed daily for $48 \mathrm{~h}$. After incubation, the cells on the membrane filter were fixed with methanol and stained with $0.05 \%$ crystal violet for $30 \mathrm{~min}$.

The cells on the upper surface of the filter were removed with a cotton swab. The membranes were then rinsed in PBS until excess stain was removed. The membranes were then were air-dried for $20 \mathrm{~min}$. The migratory cells were determined by counting the cells that migrated to the lower side of the filter by bright field microscopy at $200 \times$ magnification. Five random fields were counted for each filter, and each sample was assayed in triplicate.

\section{5-Bromodeoxyuridine incorporation (BrdU)}

BrdU incorporation assay (5-Bromodeoxyuridine incorporation) was used to evaluate the synthesis of DNA. T98G cells were seeded in 6 -well plates $\left(5 \times 10^{4} /\right.$ well $)$, followed by treatments for $72 \mathrm{~h}$, as indicated. Cells were then incubated with $10 \mu \mathrm{M}$ BrdU from $45 \mathrm{~min}$, followed by fixation in $4 \%$ formaldehyde. After this, cells were washed with PBS/ $0.2 \%$ Triton and incubated with $2 \mathrm{M}$ $\mathrm{HCl}$ for $10 \mathrm{~min}$ at room temperature. At the end of $10 \mathrm{~min}$, the cells were placed in an oven at $40^{\circ} \mathrm{C}$ for $20 \mathrm{~min}$. The blocking of endogenous peroxidase activity was carried out for 30 min with $\mathrm{H}_{2} \mathrm{O}_{2}$ (3\%) in methanol/ $\mathrm{H}_{2} \mathrm{O}$ followed by washing. The blocking of nonspecific sites was carried out with glycine and normal donkey serum for $1 \mathrm{~h}$. The cells were then incubated "overnight" with primary anti-BrdU antibody. On the following day cells were incubated for 90 minutes with biotinylated secondary antibody and then washed again with PBS/ $0.2 \%$ Triton. The secondary antibody was detected by incubation with a streptavidin-biotinylated horseradish peroxidase for $60 \mathrm{~min}$ and washed, before reaction with 3,3/- diaminobenzidine (DAB) $/ \mathrm{H}_{2} \mathrm{O}_{2}$. Cells were left in the developing solution for 2-10 min, counter-stained with $0.1 \%$ methyl green, dehydrated and mounted with Permount. The samples were photographed at random in five different fields and the percentage of BrdU positive cells was determined as a percentage of the total cell population [21].

\section{Caspase- 9 and Caspase- 3 activity assay}

T98G cells were seeded in 12 well plates $\left(5 \times 10^{4} /\right.$ well $)$ and incubated for $72 \mathrm{~h}$ with IBP, $\mathrm{PGE}_{1}$ or $\mathrm{PGE}_{2}$. After this period the cells were harvested with trypsin and centrifuged at $1500 \mathrm{rpm}$ for $2 \mathrm{~min}$. The pellet was resuspended in culture medium with treatment, $1 \mu \mathrm{l}$ FITC-LEHD-FMK substrate for caspase-3 or $1 \mu$ FITCDEVD-FMK substrate for caspase-9, and $1 \mu$ l Hoechst 33342 at $37^{\circ} \mathrm{C}$. Cells were washed and resuspended in caspase assay kit buffer. After mounting, the cells were viewed and photographed in a fluorescence microscope Nikon Optiphot-II equipped with a Cool Snap Pro camera and Image Pro Plus software.

\section{Statistical analysis}

All data are presented as the mean \pm SEM. Statistical analysis was carried out with the Graphpad InStat software. One-way ANOVA with a multiple comparison 
$t$-test was used for data analysis. Difference at level of $\mathrm{p}<0.05$ was considered to be significant.

\section{Results}

\section{Effect of IBP on cell proliferation and apoptosis}

To determine the importance of $\mathrm{PGE}_{1}$ and $\mathrm{PGE}_{2}$ to cell proliferation, T98G cells were treated with IBP, $\mathrm{PGE}_{1}$ or $\mathrm{PGE}_{2}$ for $72 \mathrm{~h}$ (Figure 1). Cell counting showed that the cell number was time and dose dependently decreased by IBP (Figure $1 \mathrm{~A})$. In contrast, the presence of $\mathrm{PGE}_{1}$ or
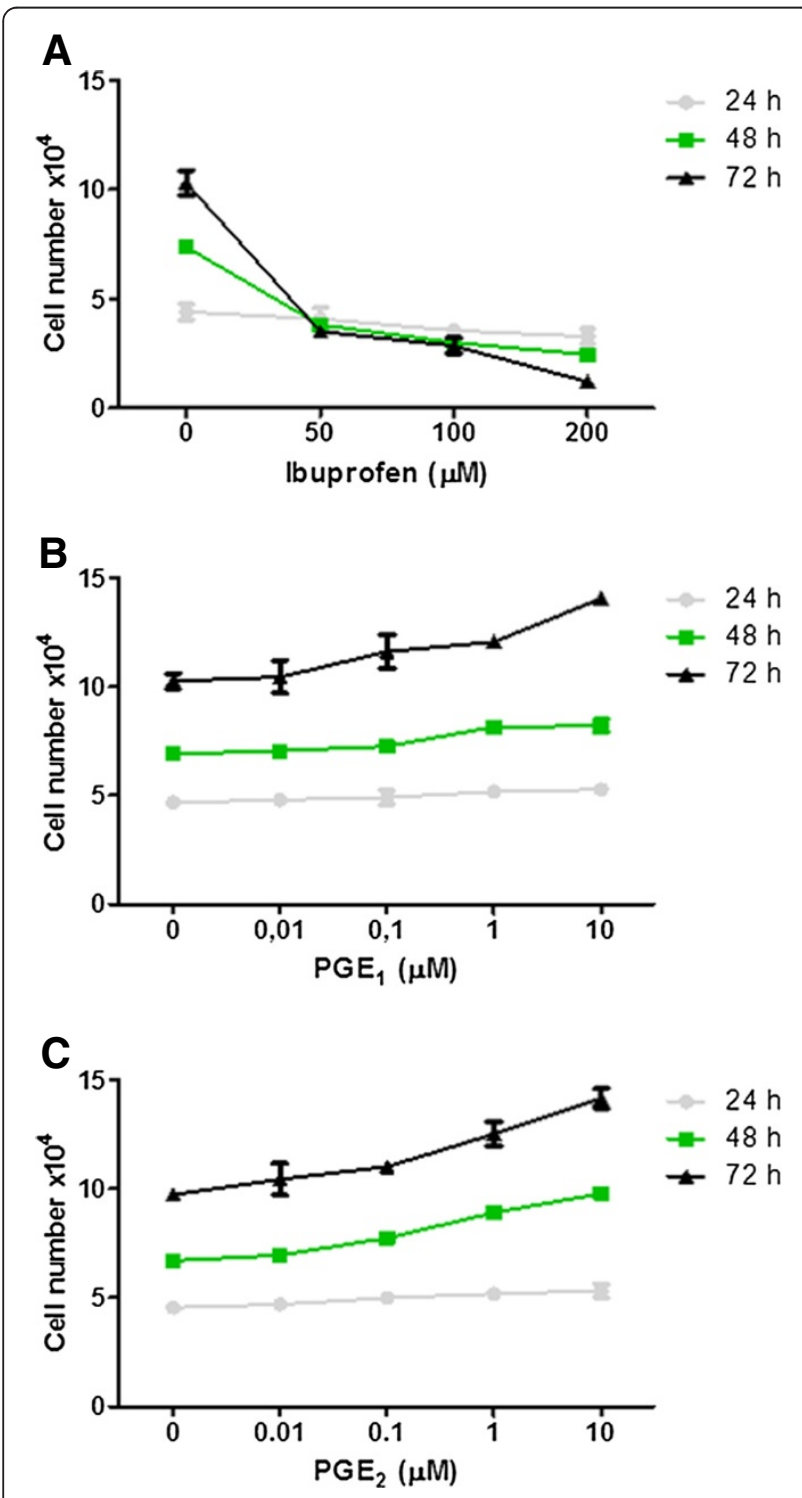

Figure 1 Effect of IBP, $\mathrm{PGE}_{1}$ and $\mathrm{PGE}_{2}$ on T98G cell number. (A) Cell number decreased dose and time dependently in the presence of IBP. (B) and (C) Cell number increased dose and time dependently in the presence of $P G E_{1}$ and $P G E_{2}$. Data are from three independent experiments in triplicate. Statistical significance, * $p<0.05$ vs control. These experiments were designed to determine the concentrations and times of incubation for each compound for the remainder of the study.
$\mathrm{PGE}_{2}$ caused a time and dose dependent increase in cell number (Figure $1 \mathrm{~B}$ and $1 \mathrm{C}$ ). Further experiments in the study used the concentrations of 25 and $50 \mu \mathrm{M}$ IBP, $10 \mu \mathrm{M} \mathrm{PGE}_{1}$ and $10 \mu \mathrm{M} \mathrm{PGE}_{2}$.

Cell counting showed that treatment with the lower dose of IBP inhibited proliferation by $45 \%$ and at $50 \mu \mathrm{M}$ this inhibition increased to 54\% (Figure 2A).

Additional experiments proved that longer periods of exposure to IBP caused an even greater decrease in cell number (Figure 3). Cell numbers at 5 days IBP were decreased by $67.8 \%$ and $79.7 \%$ for $25 \mu \mathrm{M}$ and $50 \mu \mathrm{M}$, respectively. After 10 days IBP cell number were decreased by $80.8 \%$ and $91.0 \%$ for $25 \mu \mathrm{M}$ and $50 \mu \mathrm{M}$, respectively. After 10 days IBP at $50 \mu \mathrm{M}$ the decrease in cell number (91.0\%) reached levels greater than 3 days IBP at $200 \mu \mathrm{M}(88.4 \%)$ (Figure 1A).

The fraction of cells in mitosis was quantified by calculation of the mitotic index. The fraction of cells in mitosis also decreased by $57 \%$ at $50 \mu \mathrm{M}$ IBP (Figure 2B). Similarly, the percentage of BrdU positive cells decreased by $50 \%(25 \mu \mathrm{M}$ IBP) and $65 \%(50 \mu \mathrm{M}$ IBP $)$ (Figure $2 \mathrm{C}$ ). The overall finding for cell proliferation was an approximately $55-60 \%$ decrease in the presence of $50 \mu \mathrm{M}$ IBP by the three methods used in the study.

The effects of IBP on apoptosis were analysed by Hoechst 33342 nuclear staining and visualization of caspase- 9 and caspase- 3 activity in live cells. Data from Hoechst 33342 (Figure 4A) showed a higher percentage of apoptotic nuclei in IBP cells compared to the control group. Apoptosis increased by $167 \%$ in the presence of $50 \mu \mathrm{M}$ IBP. Evidence of caspase-9 and caspase-3-like activity was seen in the form of fluorescence substrate cleavage only in the $50 \mu \mathrm{M}$ IBP treated cells and representative images are shown in Figure 4B-D.

\section{Effect of IBP on cell migration}

To investigate the effect of IBP on glioma cell migration ability, scratch migration assays and transwell migration assays were performed. As shown in Figure 5A-B, cell migration in the scratch migration assay was reduced by $40 \%$ in cells treated with $25 \mu \mathrm{M}$ ibuprofen and $74 \%$ in cells treated with $50 \mu \mathrm{M}$ IBP. Inhibition of migration was also seen in the transwell assays with $36 \%$ inhibition at $50 \mu \mathrm{M}$ compared with control cells (Figure 5C-D).

\section{Effect of $\mathrm{PGE}_{1}$ and $\mathrm{PGE}_{2}$ on cell proliferation and apoptosis}

In the case of treatment with exogenous $\mathrm{PGE}_{1}$ and $\mathrm{PGE}_{2}$, the results showed an increase of $37 \%$ with $\mathrm{PGE}_{1}$, while $\mathrm{PGE}_{2}$ increased proliferation by $45 \%$ when compared with the control (Figure 6A-B). When mitotic index was measured the presence of PGE's did not have a significant effect (Figure 6C-D). However, the percentage of BrdU positive cells in cells treated with $\mathrm{PGE}_{1}$ or 


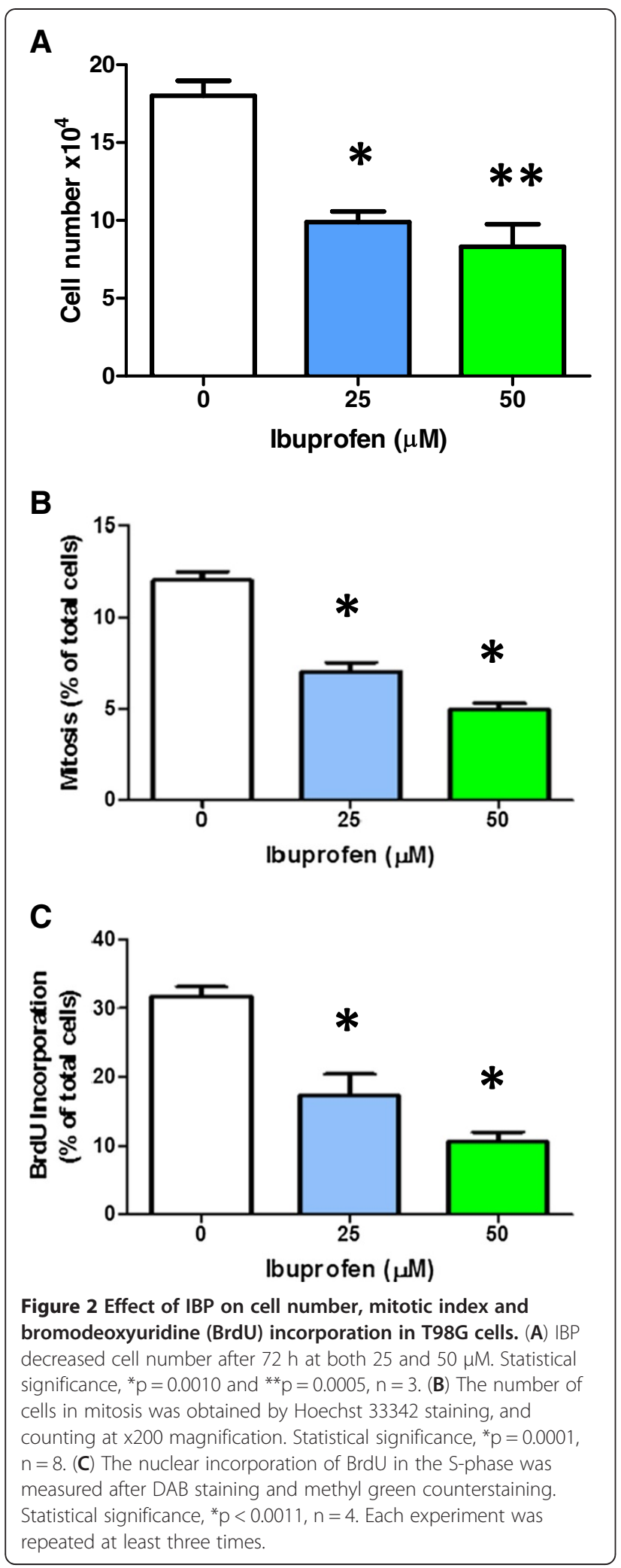

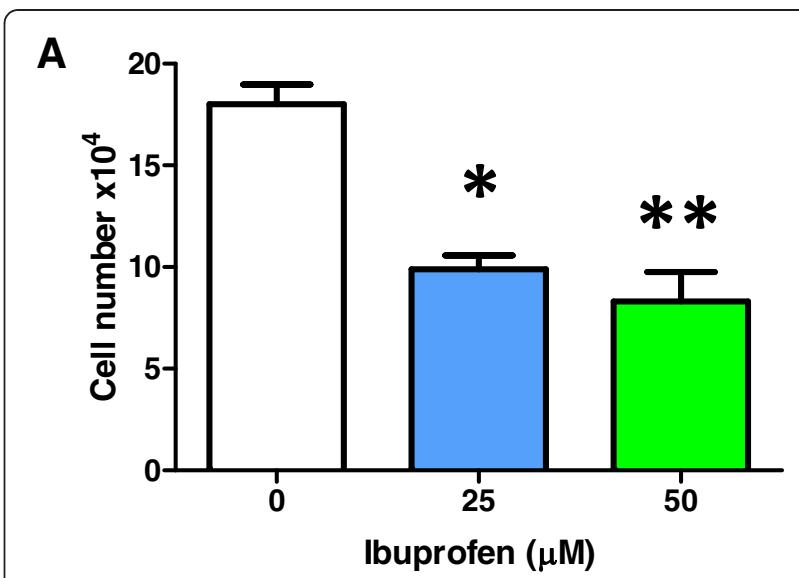

B
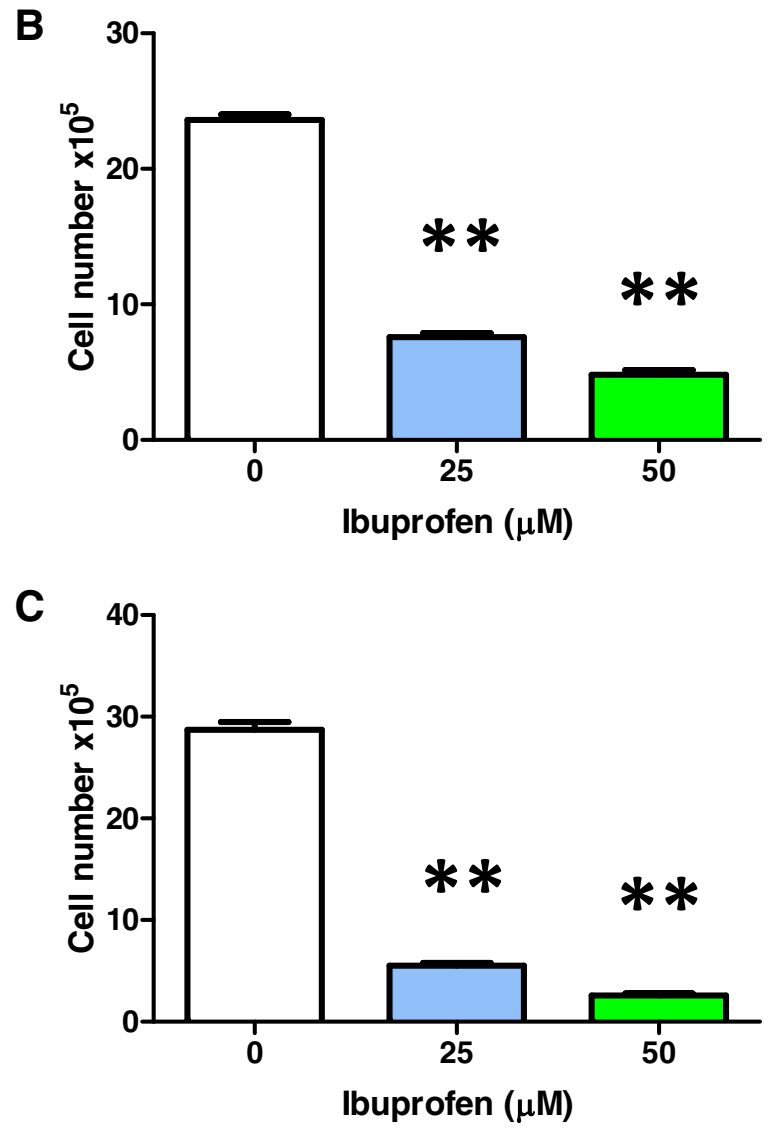

Figure 3 Effect of IBP after 3, 5 and 10 days on T98G cell number. (A-C) IBP decreased cell number after 3,5 and 10 days at both 25 and $50 \mu$ M. Statistical significance, ${ }^{*} p=0.0010$ and ${ }^{* *} p=0.0005, n=3$.

$\mathrm{PGE}_{2}$ was increased by $62 \%$ and $100 \%$, respectively (Figure 6E-F).

The effect of $\mathrm{PGE}_{1}$ and $\mathrm{PGE}_{2}$ on apoptosis was also analysed by Hoechst 33342 nuclear staining, and detection of caspase-9 and caspase-3 activity. Data from Hoechst 33342 staining (Figure $6 \mathrm{G}-\mathrm{H}$ ) showed no difference in the number of apoptotic cells. The presence 


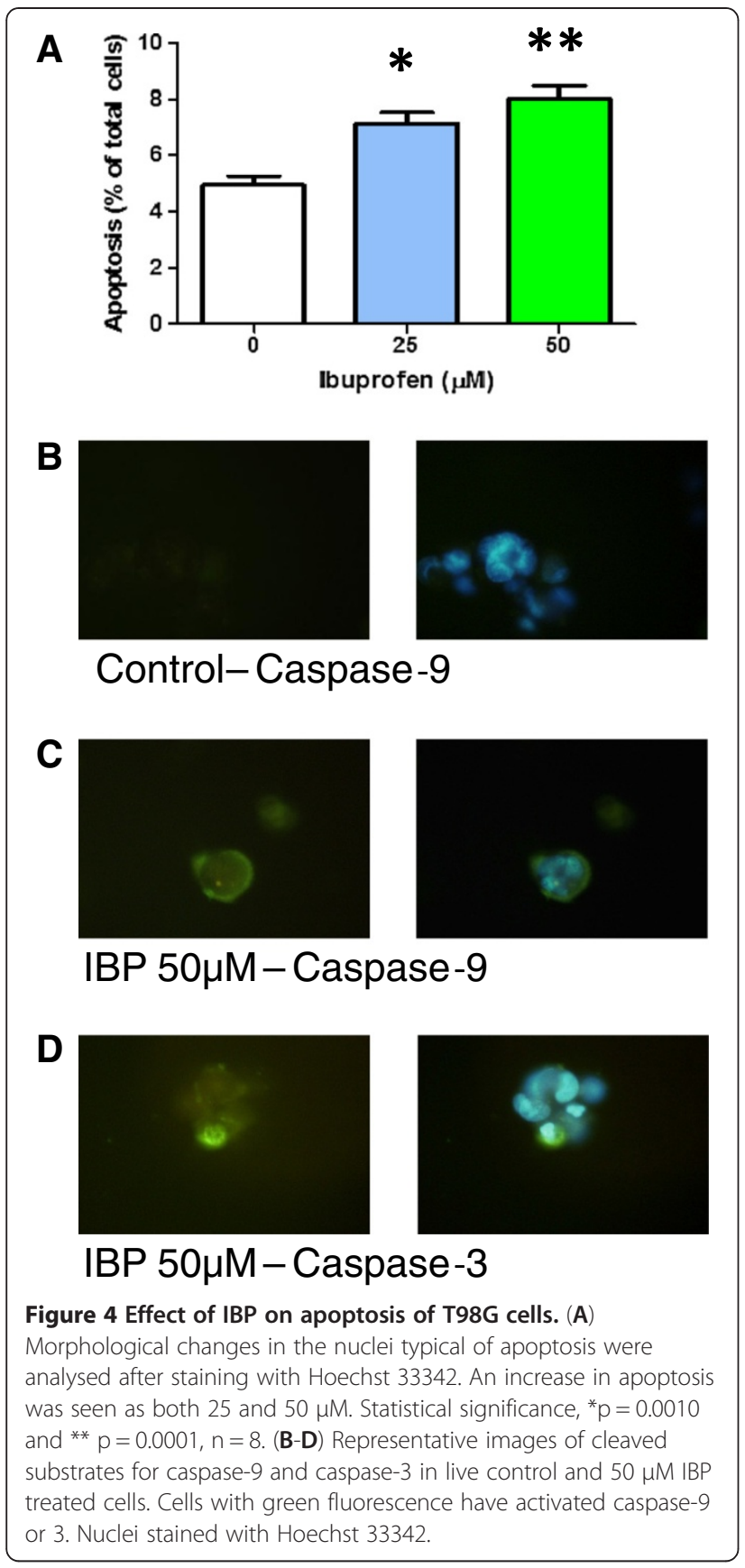

of activated caspase- 9 and caspase- 3 in the PGE treated cells was no different from the very low levels found in the control cells, unlike the results found for IBP treated cells (data not shown).

Effect of $\mathrm{PGE}_{1}$ and $\mathrm{PGE}_{2}$ on cell migration

Unlike IBP, the treatment with exogenous $\mathrm{PGE}_{1}$ and $\mathrm{PGE}_{2}$ increased cell migration in both assays. $\mathrm{PGE}_{1}$ increased migration by $43 \%$ in the scratch migration assay and by $28 \%$ in the transwell assay (Figure 7A-D). $\mathrm{PGE}_{2}$ increased migration by $44 \%$ in the scratch

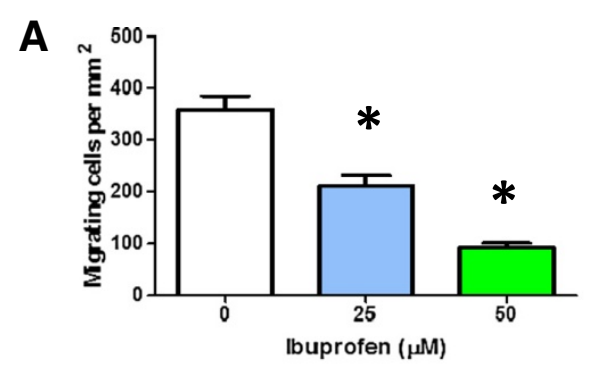

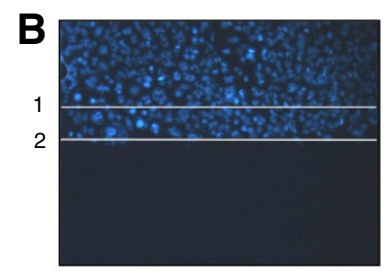

Control

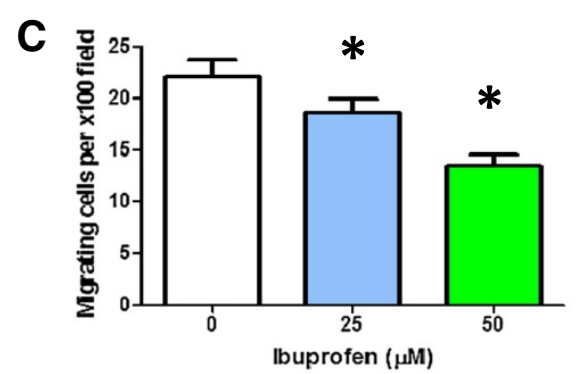

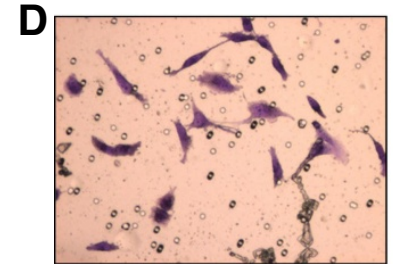

Control

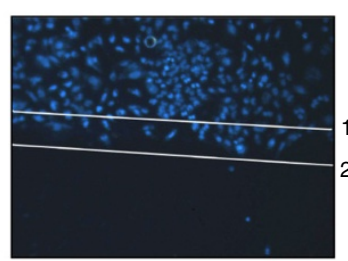

IBP $50 \mu \mathrm{M}$
Figure 5 Effect of IBP on T98G cell migration. (A) Migration of T98G in the presence or absence of $25 \mu \mathrm{M}$ or $50 \mu \mathrm{M}$ IBP in the monolayer scratch assay. Number of migrating cells per unit area. Statistical significance, ${ }^{*} p<0.05$ vs control, $n=8$ in control, $n=16$ in $25 \mu \mathrm{M}$ and $\mathrm{n}=16$ in $50 \mu \mathrm{M}$. (B) Representative images of Hoechst 33342-labelled control and $50 \mu \mathrm{M}$ IBP treated cells. Start point at time zero indicated by line1 and average maximum migratory distance possible in a $10 \mathrm{~h}$ period indicated by line 2. (C) Migration of T98G in the presence or absence of $25 \mu \mathrm{M}$ or $50 \mu \mathrm{M}$ IBP in the transwell assay. Number of migrating cells per $\times 100$ field. Statistical significance, ${ }^{*} p<0.0005$ vs control, $n=12$. (D) Representative images of crystal violet stained control and $50 \mu \mathrm{M}$ IBP treated cells.

migration assay and by $68 \%$ in the transwell assay (Figure 8A-D).

\section{Discussion}

Glioblastoma multiforme (GBM), a highly invasive and vascularized tumour, responds poorly to conventional cytotoxic therapy. In our study, we showed that IBP 

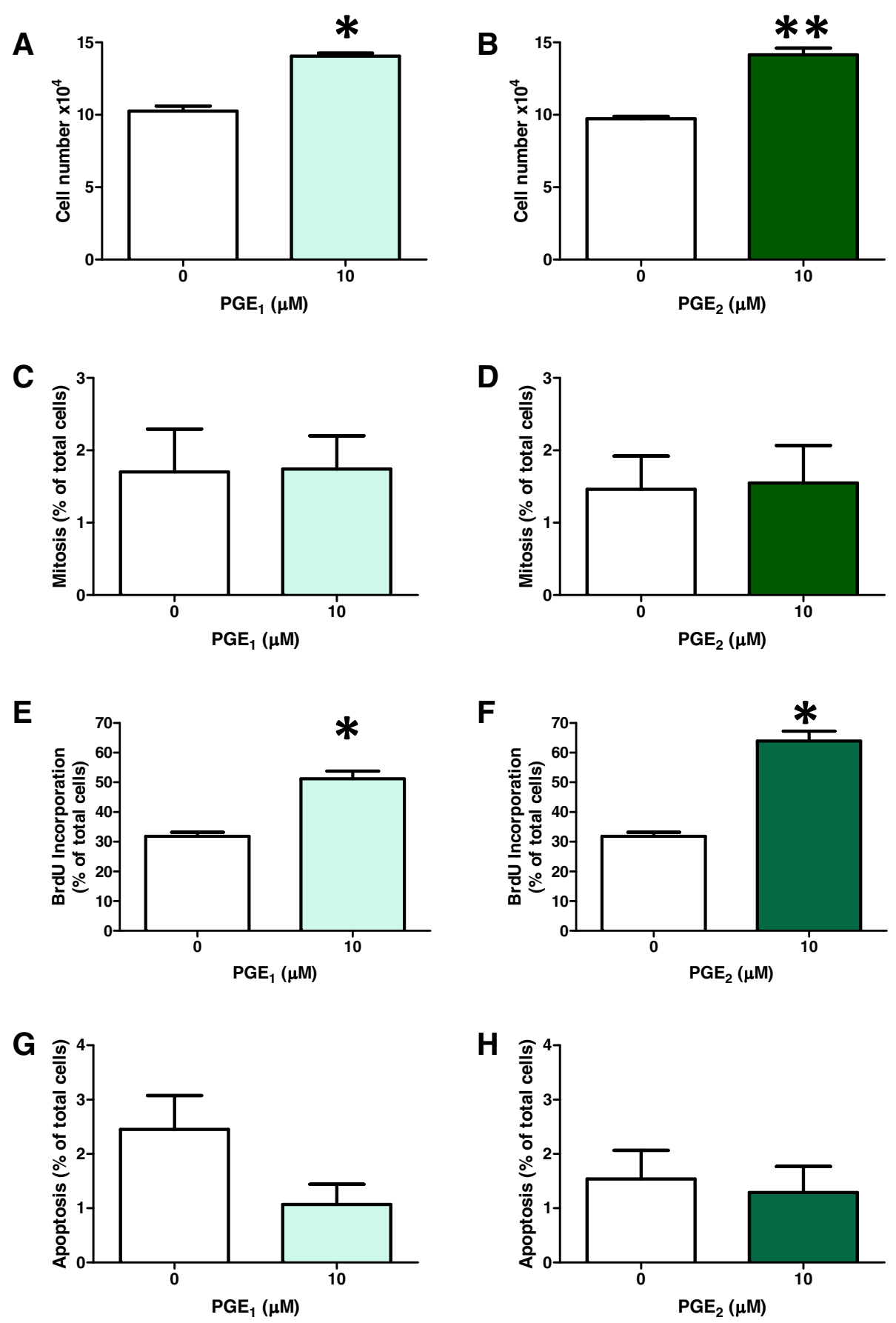

Figure 6 Effect of $\mathrm{PGE}_{1}$ and $\mathrm{PGE}_{2}$ on cell number, mitotic index, bromodeoxyuridine (BrdU) incorporation and apoptosis in T98G cells. (A) Both $\mathrm{PGE}_{1}$ and $\mathrm{PGE}_{2}$ increased cell number at $10 \mu \mathrm{M}$ after $72 \mathrm{~h}$ treatment. Statistical significance ${ }^{*} \mathrm{p}=0.0007$ and ${ }^{* *} \mathrm{p}=0.0008, \mathrm{n}=4$. (B) The number of cells in mitosis was obtained by Hoechst 33342 staining, and counting at $\times 200$ magnification. $n=8$. (C) The nuclear incorporation of $\mathrm{BrdU}$ in the S-phase was measured after DAB staining and methyl green counterstaining. Statistical significance ${ }^{*} p<0.0001, n=4$. (D)

Morphological changes in the nuclei typical of apoptosis were analysed after staining with Hoechst 33342. Each experiment was repeated at least three times.

potently inhibited proliferation, migration and induced apoptosis in T98G human glioma cells. It has been shown that several NSAIDs are able to induce glioma cell apoptosis [22]. Previous studies have shown that in various tumours a high concentration of $\mathrm{PGE}_{2}$ and a high COX-2 activity are present. Overexpression of $\mathrm{COX}-2 / \mathrm{PGE}_{2}$ in human tumors is associated with progression, invasion and angiogenesis [23-25]. However, 


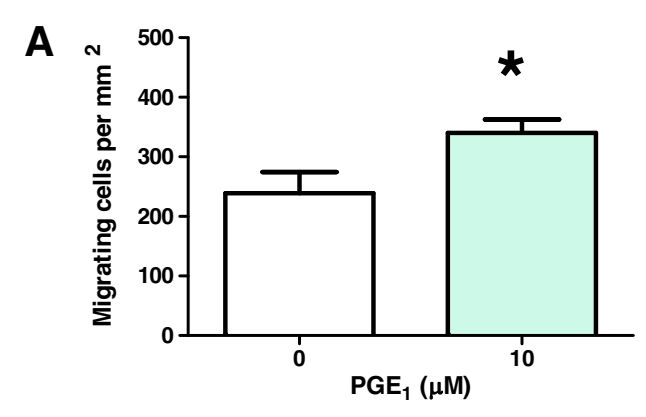

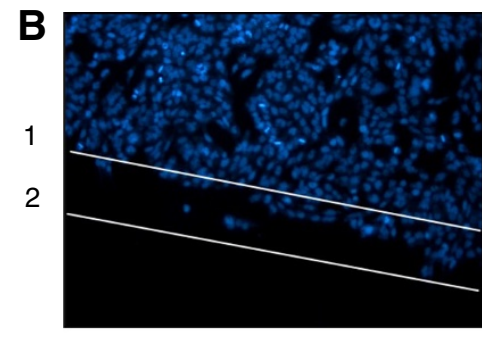

Control

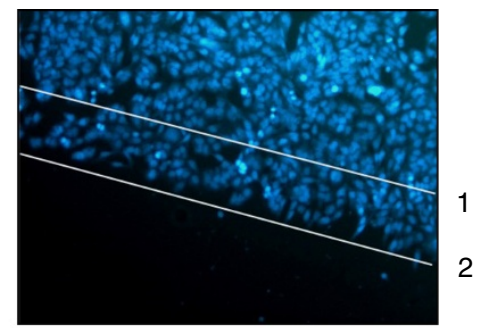

$\mathrm{PGE}_{1} 10 \mu \mathrm{M}$

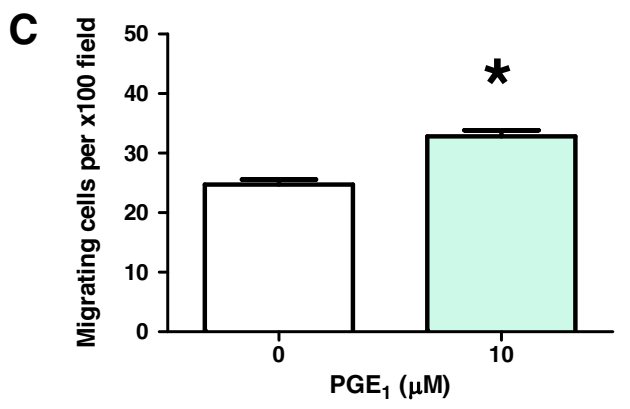

D

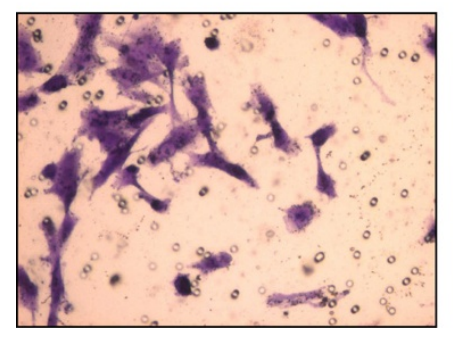

Control

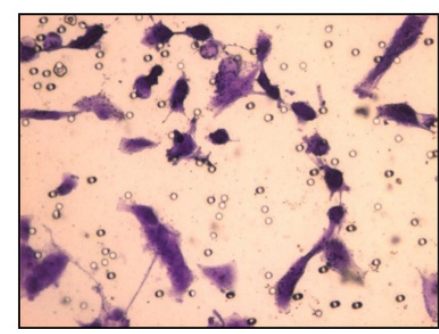

$\mathrm{PGE}_{1} 10 \mu \mathrm{M}$

Figure 7 Effect of $\mathrm{PGE}_{\mathbf{1}}$ on T98G cell migration. (A) Migration of T98G in the presence or absence of $10 \mu \mathrm{M} \mathrm{PGE}_{1}$ in the monolayer scratch assay. Number of migrating cells per unit area. ${ }^{*} p=0.0001, n=8$ (B) Representative images of Hoechst 33342 -labeled control and $10 \mu M$ PGE 1 treated cells. Start point at time zero indicated by line1 and average maximum migratory distance possible in a $10 \mathrm{~h}$ period indicated by line 2 . (C) Migration of T98G in the presence or absence of $10 \mu \mathrm{M} \mathrm{PGE}$ in the transwell assay. Number of migrating cells per $\times 100$ field. Statistical significance ${ }^{*} p=0.0001, n=16$. (D) Representative images of crystal violet stained control and $10 \mu \mathrm{M} \mathrm{PGE}_{1}$ treated cells.

the mechanism of $\mathrm{COX}-2 / \mathrm{PGE}_{2}$ up regulation in glioma cells is still poorly defined.

IBP, a generic and relatively inexpensive, non-selective COX inhibitor, is still widely used in clinical practice in the treatment of various cancers including colon and prostate cancer [3-5]. Despite enthusiasm about the potential usefulness of NSAIDs as anticancer agents, little has been reported about the effects of IBP on brain tumours. Therefore, the aim of this study was to investigate the effect of IBP upon the proliferation, migration and apoptosis processes in glioma cells.

Studies demonstrated that the proliferation and invasion of cultured glioma cell lines was inhibited in vitro by the specific COX-2 inhibitor NS-398, suggesting a functional role for COX-2/ $\mathrm{PGE}_{2}$ in glioma [26]. In our study we showed that IBP in doses of $25 \mu \mathrm{M}$ and $50 \mu \mathrm{M}$ 
A

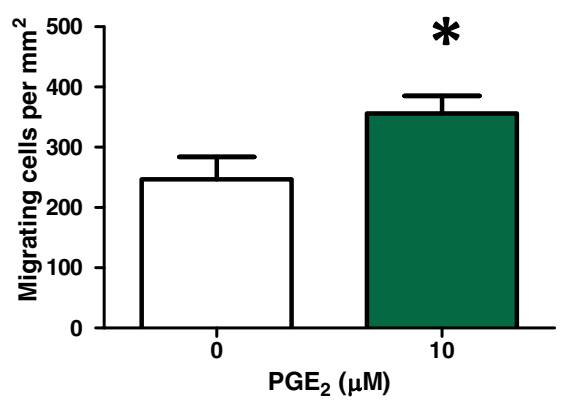

B

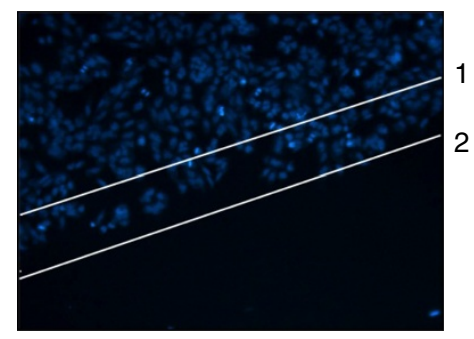

Control

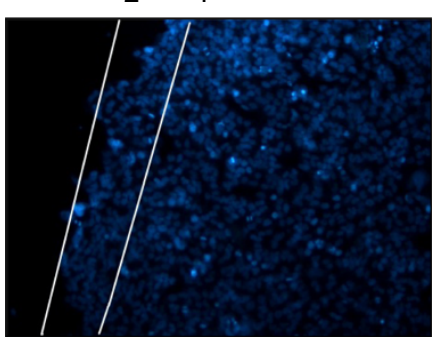

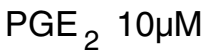

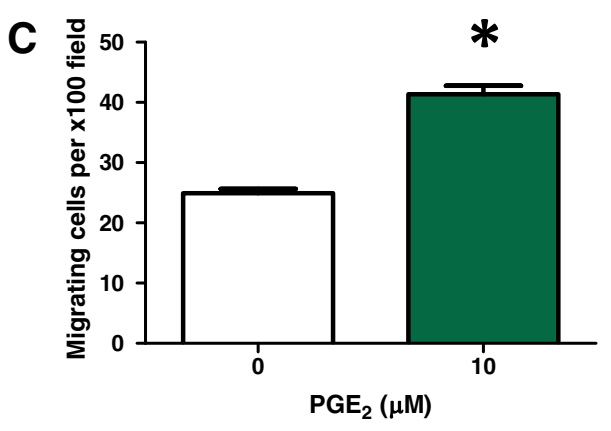

D

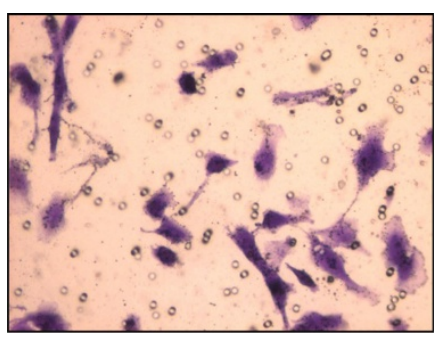

Control

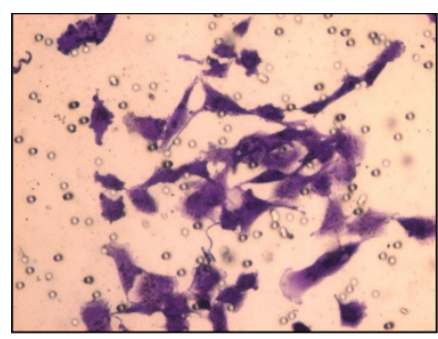

$\mathrm{PGE}_{2} 10 \mu \mathrm{M}$

Figure 8 Effect of $\mathrm{PGE}_{\mathbf{2}}$ on T98G cell migration. (A) Migration of T98G in the presence or absence of $10 \mu \mathrm{M}$ PGE ${ }_{2}$ in the monolayer scratch assay. Number of migrating cells per unit area. ${ }^{*} \mathrm{p}=0.0001, \mathrm{n}=8$ (B) Representative images of Hoechst 33342 -labeled control and $10 \mu \mathrm{M}$ PGE 2 treated cells. Start point at time zero indicated by line1 and average maximum migratory distance possible in a $10 \mathrm{~h}$ period indicated by line 2. (C) Migration of T98G in the presence or absence of $10 \mu \mathrm{M} \mathrm{PGE} 2$ in the transwell assay. Number of migrating cells per $\times 100$ field. Statistical significance ${ }^{*} p=0.0001, n=16$. (D) Representative images of crystal violet stained control and $10 \mu M P E_{2}$ treated cells.

inhibited the proliferation of T98G cells dose and time dependently. These findings are compatible with a study that showed that inhibition of COX activity and expression blocked the release of $\mathrm{PGE}_{2}$ from U87-MG human glioma cells and this generated a decrease in their proliferation [27]. In a recent study nano-prodrugs of IBP caused a greater reduction in cell proliferation in comparison with the nano-prodrugs of indomethacin or naproxen in the U87-MG cell line [28]. PGE $_{2}$ plays an important role in the pathogenesis of endometriosis. 
Inhibition of COX-2 was recently reported to decrease migration as well as invasion of human endometrial epithelial and stromal cells. Results of the study indicate that selective inhibition of $\mathrm{PGE}_{2}$ receptors EP2 and EP4 suppresses expression and/or activity of matrix metalloproteinase (MMP2 and MMP9) proteins and increases expression of tissue inhibitor of metalloproteinases (TIMP1, TIMP2, TIMP3, and TIMP4) proteins and thereby decreases migration [29]. In another study $\mathrm{PGE}_{2}$ treatment significantly increased cell adhesion, migration, and invasion in hepatocellular carcinoma (HCC) cells. In addition, the effects of $\mathrm{PGE}_{2}$ were found to be associated with focal adhesion kinase (FAK) activity [30]. Indomethacin treatment reduced $\mathrm{PGE}_{2}$ content in normal and tumour tissue colorectal cancer. This reduction in tumour tissue $\mathrm{PGE}_{2}$ content was related to significant alterations in the expression of several hundred genes including genes related to cell cycle control and apoptosis [31]. Interestingly, indomethacin-loaded nanocapsules inhibited the growth of glioma cells in vitro and the $\mathrm{C} 6$ rat glioma model in vivo $[32,33]$.

Our results demonstrated that T98G glioma cells showed signs of apoptosis after treatment with both concentrations of IBP. We found that after IBP treatment, chromatin condensation and fragmentation were increased in the nuclei. In a recent study, the treatment of U87-MG glioma cells with IBP nano-prodrugs $(25 \mu \mathrm{M}$ and $50 \mu \mathrm{M})$ resulted in a significant increase in cell death [27]. In another study the NSAID aspirin induced apoptosis by the inhibition of cyclin D1 and $\mathrm{Bcl}-2$ in the A172 glioblastoma cell line [34]. From these studies it is apparent that inhibition of PG production by NSAIDs causes the induction of apoptosis in glioma cells.

In conclusion, our results demonstrated that IBP treatment suppressed T98G human glioma cell proliferation and apoptosis in vitro. In addition IBP caused a significant inhibition of T98G migration. In contrast, the addition of either exogenous $\mathrm{PGE}_{1}$ or $\mathrm{PGE}_{2}$ caused a significant increase in cell proliferation and increased cell migration. The difference in $\mathrm{PGE}_{1}$ and $\mathrm{PGE}_{2}$ effects on cell migration may be related to the expression profile of EP and IP receptors in the T98G cell line and requires further investigation. Altering prostaglandin metabolism remains a promising target for GBM treatment and is currently being studied in our laboratory.

\section{Competing interests}

The authors declare that they have no competing interests.

\section{Authors' contributions}

RNG participated in the execution and analysis of the study. AC participated in the design and analysis of the study. Both authors read and approved the final manuscript.

\section{Funding}

The study was funded by FAPESP (Fundação de Amparo à Pesquisa do Estado de São Paulo) and CAPES (Coordenação de Aperfeiçoamento de Pessoal de Nível Superior).

Received: 13 September 2012 Accepted: 4 December 2012 Published: 11 December 2012

\section{References}

1. Ohgaki H: Epidemiology of brain tumors. Methods Mol Biol 2009, 472:42.

2. Louis DN, Ohgaki H, Wiestler OD, Cavenee WK, Burger PC, Jouvet A, Scheithauer BW, Kleihues P: The 2007 WHO Classification of Tumours of the Central Nervous System. Acta Neuropathol 2007, 114(2):97-109.

3. Ulrich CM, Bigler J, Potter JD: Non-steroidal anti-inflammatory drugs for cancer prevention: promise, perils and pharmacogenetics. Nat Rev Cancer 2006, 6(2):130-140.

4. Johnson CC, Hayes RB, Schoen RE, Gunter MJ, Huang WY: Non-steroidal anti-inflammatory drug use and colorectal polyps in the prostate, lung, colorectal, and ovarian cancer screening trial. Am J Gastroenterol 2010, 105(12):2646-2655.

5. Baron JA, Sandler RS: Nonsteroidal anti-inflammatory drugs and cancer prevention. Annu Rev Med 2000, 51:511-523.

6. de Groot DJ, de Vries EG, Groen HJ, de Jong S: Non-steroidal antiinflammatory drugs to potentiate chemotherapy effects: from lab to clinic. Crit Rev Oncol Hematol 2007, 61(1):52-69.

7. Tseng WW, Deganutti A, Chen MN, Saxton RE, Liu CD: Selective cyclooxygenase-2 inhibitor rofecoxib (Vioxx) induces expression of cell cycle arrest genes and slows tumor growth in human pancreatic cancer. J Gastrointest Surg 2002, 6(6):838-843.

8. Masferrer JL, Leahy KM, Koki AT, Zweifel BS, Settle SL, Woerner BM, Edwards DA, Flickinger AG, Moore RJ, Seibert K: Antiangiogenic and antitumor activities of cyclooxygenase-2 inhibitors. Cancer Res 2000, 60(5):1306-1311.

9. Dubois RN, Abramson SB, Crofford L, Gupta RA, Simon LS, Van De Putte LB, Lipsky PE: Cyclooxygenase in biology and disease. FASEB J 1998, 12:1063-1073.

10. Simmons DL, Botting RM, Hla T: Cyclooxygenase isozymes: the biology of prostaglandin synthesis and inhibition. Pharmacol Rev 2004, 56(3):387-437.

11. Shono T, Tofilon PJ, Bruner JM, Owolabi O, Lang FF: Cyclooxygenase-2 expression in human gliomas: prognostic significance and molecular correlations. Cancer Res 2001, 61(11):4375-4381.

12. Lalier L, Cartron PF, Pedelaborde F, Olivier C, Loussouarn D, Martin SA, Meflah K, Menanteau J, Vallette FM: Increase in PGE2 biosynthesis induces a Bax dependent apoptosis correlated to patients' survival in glioblastoma multiforme. Oncogene 2007, 26(34):4999-5009.

13. Li W, Xu RJ, Lin ZY, Zhuo GC, Zhang HH: Effects of a cyclooxygenase-1selective inhibitor in a mouse model of ovarian cancer, administered alone or in combination with IBP, a nonselective cyclooxygenase inhibitor. Med Oncol 2009, 26(2):170-177.

14. John-Aryankalayil M, Palayoor ST, Cerna D, Falduto MT, Magnuson SR, Coleman CN: NS-398, IBP, and cyclooxygenase-2 RNA interference produce significantly different gene expression profiles in prostate cancer cells. Mol Cancer Ther 2009, 8(1):261-273.

15. Janssen A, Maier TJ, Schiffmann S, Coste O, Seegel M, Geisslinger G, Grösch $\mathrm{S}$ : Evidence of COX-2 independent induction of apoptosis and cell cycle block in human colon carcinoma cells after S- or R-IBP treatment. Eur J Pharmacol 2006, 540(1-3):24-33.

16. Ribeiro G, Benadiba M, Colquhoun A, Silva DO: Diruthenium (II, III) complexes of ibuprofen, aspirin, naproxen and indomethacin nonsteroidal anti-inflammatory drugs: synthesis, characterization and their effects on tumour cell proliferation. Polyhedron 2008, 27:1131-1137.

17. Benadiba M, Dos Santos RR, Silva Dde O, Colquhoun A: Inhibition of C6 rat glioma proliferation by $[\mathrm{Ru} 2 \mathrm{Cl}(\mathrm{lbp}) 4]$ depends on changes in p21, p27, $\mathrm{Bax} / \mathrm{Bcl} 2$ ratio and mitochondrial membrane potential. J Inorg Biochem 2010, 104(9):928-935.

18. Iyú $D$, Jüttner M, Glenn JR, White AE, Johnson AJ, Fox SC, Heptinstall S: PGE1 and PGE2 modify platelet function through different prostanoid receptors. Prostaglandins Other Lipid Mediat 2011, 94(1-2):9-16.

19. Colquhoun A, Curi R: Effects of saturated and polyunsaturated fatty acids on human tumor-cell proliferation. Gen Pharmacol 1998, 30(2):191-194. 
20. Ramos KL, Colquhoun A: Protective role of glucose-6-phosphate dehydrogenase activity in the metabolic response of $\mathrm{C} 6$ rat glioma cells to polyunsaturated fatty acid exposure. Glia 2003, 43(2):149-166.

21. Miyake JA, Benadiba M, Colquhoun A: Gamma-linolenic acid inhibits both tumour cell cycle progression and angiogenesis in the orthotopic $\mathrm{C} 6$ glioma model through changes in VEGF, Flt1, ERK1/2, MMP2, cyclin D1, pRb, p53 and p27 protein expression. Lipids Health Dis 2009, 8:8.

22. Kardosh A, Blumenthal M, Wang WJ, Chen TC, Schönthal AH: Differential effects of selective COX-2 inhibitors on cell cycle regulation and proliferation of glioblastoma cell lines. Cancer Biol Ther 2004, 3(1):55-62.

23. Sheng $\mathrm{H}$, Shao J, Washington MK, DuBois RN: Prostaglandin E2 increases growth and motility of colorectal carcinoma cells. J Biol Chem 2001, 276(21):18075-18081.

24. Wang D, Dubois RN: Eicosanoids and cancer. Nat Rev Cancer 2010, 10(3):181-193

25. Menter DG, Dubois RN: Prostaglandins in cancer cell adhesion, migration, and invasion. Int I Cell Biol 2012, 2012:723419.

26. Chiu WT, Shen SC, Chow JM, Lin CW, Shia LT, Chen YC: Contribution of reactive oxygen species to migration/invasion of human glioblastoma cells U87 via ERK-dependent COX-2/PGE(2) activation. Neurobiol Dis 2010, 37(1):118-129.

27. Payner T, Leaver HA, Knapp B, Whittle IR, Trifan OC, Miller S, Rizzo MT: Microsomal prostaglandin E synthase-1 regulates human glioma cell growth via prostaglandin E(2)-dependent activation of type II protein kinase A. Mol Cancer Ther 2006, 5(7):1817-1826.

28. Lee BS, Yuan, Xu O, Ko MK, Nalla AK, Frankiel I, Shear T, Black KL, Yu JS: Nanoprodrugs of NSAIDs Inhibit the Growth of U87-MG Glioma Cells. J Nanomater 2010, 372(1-2):112-124.

29. Lee J, Banu SK, Subbarao T, Starzinski-Powitz A, Arosh JA: Selective inhibition of prostaglandin E2 receptors EP2 and EP4 inhibits invasion of human immortalized endometriotic epithelial and stromal cells through suppression of metalloproteinases. Mol Cell Endocrinol 2010, 30(3):377-386.

30. Bai XM, Zhang W, Liu NB, Jiang H, Lou KX, Peng T, Ma J, Zhang L, Zhang H, Leng J: Focal adhesion kinase: important to prostaglandin E2-mediated adhesion, migration and invasion in hepatocellular carcinoma cells. Oncol Rep 2009, 21(1):129-136.

31. Gustafsson A, Andersson M, Lagerstedt K, Lönnroth C, Nordgren S, Lundholm K: Receptor and enzyme expression for prostanoid metabolism in colorectal cancer related to tumor tissue PGE2. Int J Oncol 2010, 36(2):469-478.

32. Bernardi A, Frozza RL, Jäger E, Figueiró F, Bavaresco L, Salbego C, Pohlmann AR, Guterres SS, Battastini AM: Selective cytotoxicity of indomethacin and indomethacin ethyl ester-loaded nanocapsules against glioma cell lines: an in vitro study. Eur J Pharmacol 2008, 586(1-3):24-34.

33. Bernardi A, Braganhol E, Jäger E, Figueiró F, Edelweiss MI, Pohlmann AR, Guterres SS, Battastini AM: Indomethacin-loaded nanocapsules treatment reduces in vivo glioblastoma growth in a rat glioma model. Cancer Lett 2009, 281(1):53-63.

34. Kim SR, Bae MK, Kim JY, Wee HJ, Yoo MA, Bae SK: Aspirin induces apoptosis through the blockade of IL-6-STAT3 signaling pathway in human glioblastoma A172 cells. Carcinogenesis 2009, 30(3):377-386.

doi:10.1186/1476-511X-11-171

Cite this article as: Gomes and Colquhoun: $E$ series prostaglandins alter the proliferative, apoptotic and migratory properties of T98G human glioma cells in vitro. Lipids in Health and Disease 2012 11:171.

\section{Submit your next manuscript to BioMed Central and take full advantage of:}

- Convenient online submission

- Thorough peer review

- No space constraints or color figure charges

- Immediate publication on acceptance

- Inclusion in PubMed, CAS, Scopus and Google Scholar

- Research which is freely available for redistribution 